\title{
Character Education Values in the Basic Movement of Tuping Dance
}

\author{
Armayyeni Nurillia Marsim ${ }^{1},{ }^{*}$ Mulyanto $^{2}$, Sudiyanto $^{3}$ \\ ${ }^{1,2,3}$ Graduate School of Sebelas Maret University, Surakarta, Indonesia \\ *armayyeni7@gmail.com
}

\begin{abstract}
Tuping dance is a dance originating from South Lampung which depicts army troops. This dance is usually performed during traditional celebrations in the South Lampung area, especially in Kuripan village, Penengah sub-district, South Lampung district. Tuping dance consists of 14 types of movements consisting of negakh, lelagoan, tikol, silat awal, cangget, tolak tebing, silat tikol, silat khalut, tepuk agas, lelagoan lapah, silat mundukh, ngelap bawah, buka topeng, dan mulang. This movement was adopted from the daily activities of the Tuping dancer troops who mingled with the community and also acted as scouts, so that the movement was dominated by Silat Lampung and was also inserted with funny movements. Tuping dance is a cultural product of the past that is continuously maintained and preserved by the local community. The preservation of this culture can be carried out through the cultivation of character education values contained therein. So that dancers can not only dance but can learn about good character. This study aims to identify the value of character education contained in the basic movements Tuping South Lampung dance. The methodology used is qualitative where data is obtained through observation, documentation, interviews, and literature study. The validity of the data used were source triangulation and informant reviews. From the results of the analysis, the researcher obtained 2 values of character education in the Tuping Lampung Selatan dance, namely: (1) the communicative value can be seen from the movements of Lelagoan and Lelagoan Lapah, and (2) the value of social care is found in the Cangget movement.
\end{abstract}

Keywords: Tuping dance, basic movements, character education

\section{INTRODUCTION}

Today's education is faced with the development of advances in information technology and is faced with very diverse social and cultural realities. Education is required to adapt to the circumstances of the surrounding community, where there are various kinds of deviations committed. Such as juvenile delinquency, fights between groups and various other deviant morals. In this case, education is expected to be a forum for fostering the younger generation by building character directly or indirectly. Character education in students can be carried out as early as possible, one of which is by inserting it into school learning.

Dance learning in schools understands the value of dance education in accordance with the natural state of children who have a tendency to move and prefer good communicative language. Art education has its own characteristics that make it different from others, this is related to its characteristics, including multilingual, multidimensional and multicultural[1]. This educational value can also be used to instill character in children. Because character itself refers to a series of attitudes, behavior, motivation, skills, and shows how someone behaves[2]. Dance as a national education also has a function to develop the character and potential of students in accordance with the national character[3]. Character education expressed through the art of dance,

Character education through traditional arts, in this case traditional dances, is expected to foster the mental and self-confidence of everyone so that it will indirectly form and develop the values contained in traditional dances that are maintained and implemented in everyday life. These values come from religion, Pancasila, culture and the goals of national education.

The background of the importance of doing this research is the result of concern in managing the character of society which is increasingly rare and concerning. This condition causes most people to lose their identity. This social and cultural crisis was witnessed by many people. Decreased respect and 
obedience to law, ethics, morals and social decency, as well as the increasing number of conflicts that occur in terms of politics, ethnicity and religion. To increase this awareness, there is a need for guidance that is not only limited to the school or campus environment, but also through community social activities. Besides being able to foster self-confidence in the culture that exists in each community group, it can also contribute to character education, one of which is through traditional dances.

Traditional dances in the Lampung area are very diverse, one of which is the Tuping dance. Tuping dance is a dance that originates from the South Lampung area. This dance has a background of a mask which has 12 (twelve) types of facial characters, each character symbolizing its respective skills[4]. The facial characters include: 1) Tuping Irung Tebak/ cross nose, (2) Tuping Irung Cungak/ nose looks up, (3) Tuping Luah Takhing/ fangs out, (4) Tuping Jangguk Khawing/ long beard irregular, (5) Tuping Banguk Khabit/ flat mouth, (6) Tuping Bekhak Banguk/ wide mouth, (7) Tuping Mata Sipit/ slanted eyes, (8) Tuping Banguk Kicut/ mouth swollen, (9) Tuping Pudak Bebail Female face, (10) Tuping Mata Kedugok/ sleepy eyes, (11) Tuping Matakicong/ one eye, (12) Tuping Irug Pesek/ short nose.

South Lampung is one of the regencies which in ancient times was occupied by a keratuan namely Keratun Darah Putih which became a milestone for the spread of Islam in Lampung Province. One of the descendants of Keratuan Darah Putih, Radin Intan II, was one of the heroes of nationalism who inspired Tuping's figure. Tuping dance itself is still preserved as a cultural heritage for the people of South Lampung, especially in Kuripan village.

This study aims to identify the value of character education contained in the basic movements of the Tuping South Lampung dance. Considering that this dance is a cultural heritage that must be preserved, it is very important to be researched and made into a scientific work, with the intention of being a documentation material as well as introducing the existence of the Tuping South Lampung dance.

\section{LITERATURE REVIEW}

\subsection{Variety of Dance Movements}

Dance movements are body movements that are in harmony and rhythm so that they produce works of art that are performed at certain places and times. Movement in dance functions as a medium of communication between dance stylists, dancers and also the audience. The basic movements of the dance consist of hand movements, footwork, head movements, and body movements[5]. Motion is also divided into two forms, namely pure motion and meaningful motion[6]. Pure motion, namely the original gesture without any meaning behind it, this movement is only concerned with artistic or beauty. Meanwhile, meaningful motion is a movement created with a specific meaning, where a dance stylist wants to convey something.

Movement is the basis of expression, therefore motion is found as an expression of emotional experience which is expressed through irrational medium, namely body movement or whole body movement[7]. The body is the main tool and body movements are the basic media for expressing dance art expressions. The aspect of motion in its form or form is called space, its rhythm is called time or tempo, and its energy is called energy or energy.

\subsection{Tuping Dance}

Tuping dance is a dance originating from South Lampung which depicts army troops. Tuping in Indonesian means mask. This dance has a background of a mask which has 12 (twelve) types of facial characters, each character symbolizing its respective skills [4]. The facial characters include: (1) Tuping Irung Tebak/ cross nose, (2) Tuping Irung Cungak/ nose looks up, (3) Tuping Luah Takhing/ fangs out, (4) Tuping Jangguk Khawing/ long beard irregular, (5) Tuping Banguk Khabit/ flat mouth, (6) Tuping Bekhak Banguk/ wide mouth, (7) Tuping Mata Sipit/ slanted eyes, (8) Tuping Banguk Kicut/ mouth swollen, (9) Tuping Pudak Bebai/ Female face, (10) Tuping Mata Kedugok/ sleepy eyes, (11) Tuping Matakicong/ one eye, (12) Tuping Irug Pesek/ short nose.

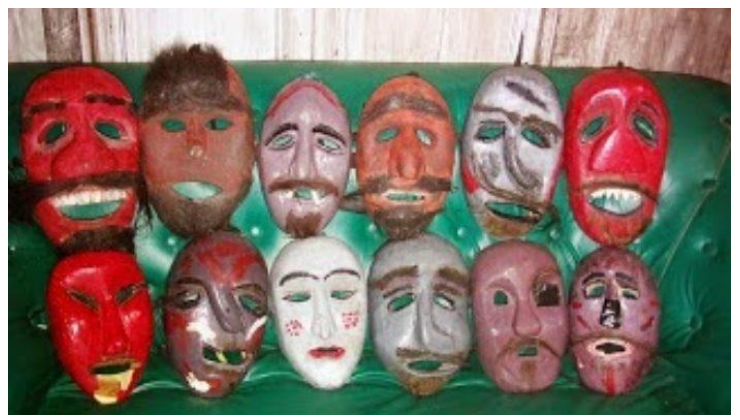

Figure 1. Tuping characters (source: South Lampung tourism office team)

This dance is a cultural heritage that is often functioned as part of the ritual of celebrating traditional greatness in the South Lampung area, but as the era progresses, this dance has changed its function to become entertainment for the community. Dance itself, if grouped based on its function, can be used as entertainment, communication tools, ceremonies or rituals, as well as educational functions[8]. Dance in the realm of ritual position functions as a medium for the implementation of the event, without his presence the ceremony cannot take place. Dance in the realm of entertainment serves as a means of expressing joy. Dance in the realm of spectacle was created with the aim of beauty, so that it prioritizes aesthetic satisfaction. Dance in the educational role of art serves to develop the ability of each student to transmit cultural heritage, 
Tuping himself during the war not only as a scout but also as an invader and attacking with his various knowledge and pretending to act funny in the community so that the enemy could not suspect their disguise so that they could briefly attack then avoid entering the forest because what they used was leaves. Tuping for the people of South Lampung, especially Keratuan Darah Putih, meant as the Radin Intan II Guerrilla Force assigned to 12 (twelve) posts, starting from the Sunda Strait to Tanjung Cina Kota Agung.

\subsection{Character building}

Character is the basic value of behavior which becomes the reference value for human interaction. Character can come from the innate nature and habituation of individuals with their environment which can be seen through the socialization process with other individuals [9]. Character is a way of thinking and behaving that characterizes each individual to live and work together, both within the family, community, nation, and state [10]. These behavioral values relate to God Almighty, self, fellow human beings, the environment, and nationality which are manifested in thoughts, attitudes, feelings and actions based on religious norms, law, manners, culture and customs. So it can be said that character education is the values that are manifested in attitudes and behaviors that have a relationship to the environment based on existing norms in society. These norms can support the development of both social, emotional, and ethical students.

The function of character education includes (1) developing basic potentials to be good-hearted, goodminded and the nation's behavior, (2) strengthening and building multicultural national behavior, (3) increasing competitive national civilization in world relations[11]. In addition, character education also has a very vital function in shaping moral values in students. These values come from religion, Pancasila, culture, and the goals of national education. In particular, character education has three main functions, namely: (1) formation and development of potential; (2) improvement and strengthening; (3) filter. These three main functions can be used as a reference in developing the potential of students in cultivating character values[12].
Character education consists of 18 interrelated components, namely religious, honest, tolerance, discipline, hard work, creative, independent, democracy, curiosity, national spirit, love of the country, respect for achievement, communicative, love of peace, likes reading, cares about the environment, cares about social, and is responsible [13]. The purpose of character education is in the form of individual, social, and cultural responses that surround it, to be able to forge oneself to be perfect so that the potential that exists within is fully developed [14]. The importance of the purpose of character education as a form of behavior, by providing space for exemplary figures and a conducive environment for growth. This is necessary so that a child's growth and development can occur optimally and run in a positive direction.

\section{RESEARCH METHODOLOGY}

This scientific work is the result of research on cultural arts, especially the Tuping dance in Kuripan village, Penengah District, South Lampung Regency. This study used descriptive qualitative method. The data in this study are in the form of character education values contained in the basic movements of the Tuping South Lampung dance, with the data sources coming from choreographers, dance artists, and first dancers. Data collection techniques used were observation, interviews, documentation, and literature study. The validity of the data used were source triangulation and informant reviews.

\section{RESULTS AND DISCUSSION}

\subsection{Basic Tuping Dance Movements}

Tuping dance consists of 14 types of movements consisting of negakh, lelagoan, tikol, silat awal, cangget, tolak tebing, silat tikol, silat khalut, tepuk agas, lelagoan lapah, silat mundukh, ngelap bawah, buka topeng, dan Mulang [16]. The movement was adopted from the daily activities of the Tuping dancer troops who mingled with the community and also acted as scouts, so that the movement was dominated by Silat Lampung and was also inserted with funny movements. Based on the analysis of the characteristics of the movements, there are three types of dance movements that contain character education values, namely the Lelagoan, Lapah, and Cangget movements.

Tabel 1. Variety of Tuping Dance Movements

\begin{tabular}{|l|l|l|l|l|}
\hline 1 & Lelagoan & $\begin{array}{l}\text { Kepala diangguk-anggukan } \\
\text { keatas dan ke bawah. }\end{array}$ & $\begin{array}{l}\text { T-8 } \\
\text { Tangan diletakkan didagu. } \\
\text { Tangann kanan direntangkan } \\
\text { kedepan. }\end{array}$ \\
Hitungan 1-8 & Hitungan 1-4 & Hitungan 5-8 Hitungan 1-2 & $\begin{array}{l}\text { Langkahkan kaki kiri kedepan } \\
\text { dan cundang diarahkan kedepan. }\end{array}$ \\
\hline
\end{tabular}




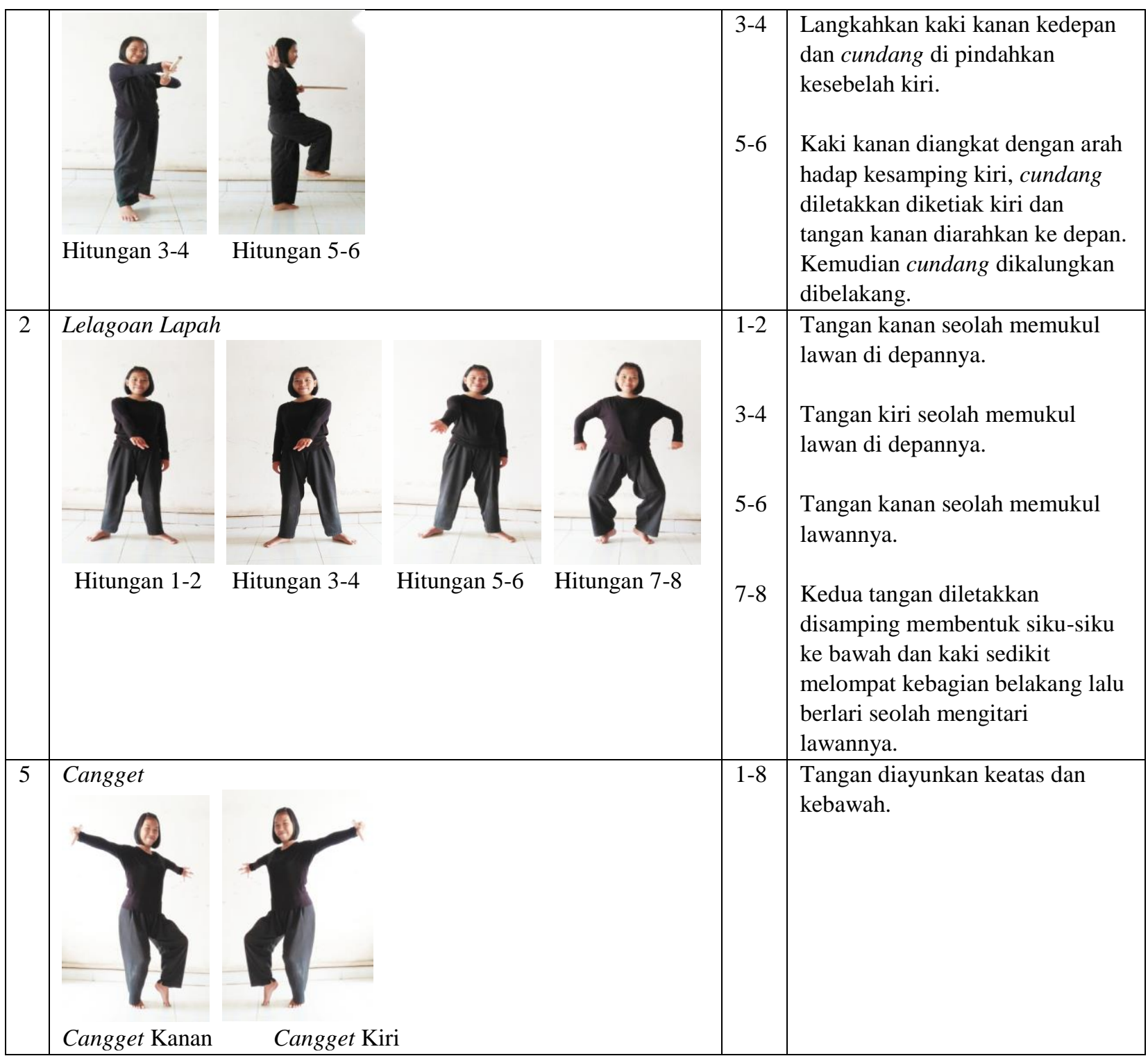

\subsection{Character Education Values in the Basic Movement of Tuping Dance}

\section{a. Communicative Value}

The communicative value in the Tuping Lampung Selatan dance can be seen from the motion of Lelagoan and the motion of Lelagoan Lapah. Communicative means being able to relate well. Education always pays attention to the basics of good communication[17]. Communicative value is related to actions that show a pleasure to talk, socialize, and cooperate with other people[13]. This can create togetherness in social life. The value of togetherness that must be instilled and nurtured is very simple, namely interacting, sharing and synergizing[18].

Based on the characteristics of their movements, the various movements of Lelagoan and Lelagoan Lapah in a simple interpretation look like a group of people who are fighting and joking. This shows that a person always communicates with others, both visually and verbally.

\section{b. Value of Social Care}

Another value of social care that is reflected in the Tuping South Lampung dance is the Cangget variety of movements. The cangget movement is indeed used as a means of socialization for young people and Lampung traditional elders[19]. The name of this movement was adopted from a traditional meeting called Cangget

\section{CONCLUSION}

Tuping dance is a dance originating from Khuripan village, Penengah District, South Lampung Regency. This dance has 14 types of movements which are adopted from the daily activities of the Tuping troops who mingle with the community and also as scouts.Based on the analysis of the characteristics of their movements, there 
are three types of dance movements that contain character education values, namely the variety of movements of Lelagoan, Lelagoan Lapah, and Cangget. The values of character education are communicative values and social care values.

\section{ACKNOWLEDGMENTS}

We thank Mr. Budiman Yakub, SE., Prasetyo Waluyo Sejati, Mr. Darmawan for collaborating as resource persons in this research. Not to forget, we would like to thank Sebelas Maret University and ICALC and their reviewers.

\section{REFERENCES}

[1] Ambarwangi, Sri. (2013). Multicultural Education in Schools through Traditional Art Education. Harmonia Journal of Art Research and Education, Volume 13, Number 1. DOI: https://journal.unnes.ac.id/nju/index.php/harmonia/ article/view/2535

[2] Sudarso, Robert Choi. 2017. The values of character education contained in the traditional dances of the Mentawai tribe. Proceedings of TEP \& PDs Transformation of 21st Century Education Theme 7 Number $17 \quad$ Pages $1081 \quad$ - 1089. DOI:http://pasca.um.ac.id/conferences/index.php/s ntepnpdas/article/viewFile/980/652.

[3] Arisyanto, Pranesa., Et al. (2018). Dance Extracurricular Learning to Cultivate Character for Students of SD Negeri Gayamsari 02 Semarang. Journal of Education and Art Studies Volume 3 Number 1. DOI:http://jurnal.untirta.ac.id/index.php/JPKS/artic le/view/4062

[4] Team of the Tourism and Culture Office of South Lampung Regency. (2015). History of South Lampung.

[5] Hadi, Y. Sumandiyo. (2007). Choreography of Form, Technique and Content. Yogyakarta.

[6] Khasanah, Nurul. (2009). Archipelago dances. Bekasi: Azka Press.

[7] Mustika, I Wayan. (2013f). Basic Techniques of Lampung Dance Movements. Bandar Lampung: Anugrah Utama Raharja (AURA) printing \& publishing.

[8] Hidayatullah, Riyan. (2017a). Introduction to the Performing Arts. Yogyakarta: Arttex.

[9] Harmawati, Yuni., Et al. (2016). Cultural Values of the Dieng Culture Festival Tradition as Local Wisdom to Build National Character. Journal of Urban Society's Arts Volume 3 Number 2.
DOI:http://journal.isi.ac.id/index.php/JOUSA/articl e/viewFile/1477/328

[10] Zubaedi. (2011). Character Education Design Concept and Its Application in Educational Institutions. Jakarta: Kencana Media Group.

[11] Samani, Muchlas., And Hariyanto. (2017). Concept and Character Education Model. Bandung: PT Remaja Rosdakarya.

[12] Ministry of National Education, Research and Development Agency for Curriculum Center. (2010). Development of Cultural Education and National Character. Jakarta: Ministry of National Education

[13] Daryanto and Suryatri, Darmiatun. (2013). Character Education in School. Yogyakarta: Gava Media.

[14] Rosala, Dedi. (2016). Learning Cultural Arts Based on Local Wisdom in an Effort to Build Student Character Education in Elementary Schools. Rhythm of the Journal of Art and Design and Its Learning Volume 2 Number 1. DOI:https://ejournal.upi.edu/index.php/ritme/articl e/viewFile/5078/3539

[15] Raharjo, Sabar Budi. (2010). Character Education as an Effort to Create Noble Morals. Journal of Education and Culture Volume 16 Number 3. DOI:https://www.neliti.com/publications/123218/p end Pendidikan-k Character-sebagai-]-menciptaakhlak-mulia

[16] Sejati, Prasetyo Waluyo (47th.). First Dancer, interviewed on March 28, 2017 at intan studio, Kuripan Village, Penengah District, South Lampung Regency, Lampung Province.

[17] Trilling and Fadel. (2009). 21st century skills: learning for life in our times. Jossey Bass: USA.

[18] Afryanto, Suhendi. (2013). Internalization of Mutual Values through Gamelan Art Learning (Character Education for Students). Journal of Arts \& Culture Stage Volum 23, Number 1. Doi:https://jurnal.isbi.ac.id/index.php/panggung/art icle/view/85/85

[19] Jacob, Budiman (61th.). Advisor for Keratuan Darah Putih, interviewed on February 23, 2020 at his house, Kuripan Village, Penengah District, South Lampung Regency, Lampung Province. 